\title{
SUNK COSTS, CONTESTABILITY, AND \\ THE LATENT CONTRACT MARKET
}

\author{
by \\ Chris Stefanadis* \\ Current Version: March 1999 \\ First Version: November 1998
}

\begin{abstract}
The idea that an industry with sunk costs may be contestable even in the absence of long-term contracts has received little attention from formal economic theory yet is popular among monopolists facing antitrust suits. The paper formally illustrates the argument. In an infinitely repeated game, there exists a class of contestable outcomes in which the monopolist sells only on the spot market and charges low prices along the equilibrium path to prevent customers from resorting to long-term contracts. Then, the crucial test for contestability is the level of transaction costs in the latent contract market.
\end{abstract}

I thank Will Baumol, Edward Green, and Hal Varian for helpful suggestions. The views expressed in this paper are those of the author and do not necessarily reflect the views of the Federal Reserve Bank of New York or the Federal Reserve System.

* Payment System Studies, Research Dept., Federal Reserve Bank of New York, 33 Liberty Street, New York, NY 10045-0001, e-mail: chris.stefanadis@ny.frb.org, tel: (212) 720-6178. 


\section{INTRODUCTION}

In antitrust cases, contestability is one of the favorite arguments of incumbent monopolists. High market shares, the argument runs, do not translate into monopoly power because of the existence of potential competition. ${ }^{1}$ Yet this claim is often dismissed as self-serving by formal economic theory. The latter states that an industry with sunk costs cannot be contestable unless equilibrium transactions take the form of very long-term contracts, with terms equal to the life span of the sunk investment.

This paper demonstrates that the concept of contestability may be applicable to a much wider range of industries than that suggested by the literature. An industry with sunk costs can be contestable even if it exhibits short-term transactions in equilibrium. A set of formal assumptions, thus, exists under which the monopolist's view makes sense. Exploring this possibility is important for public policy because numerous defendants in antitrust cases claim contestability although they operate in industries with short-term transactions (e.g., Civil Aeronautics Board hearings, Microsoft case). ${ }^{2}$

The notion that an industry facing sunk costs may be perfectly contestable is introduced by Grossman [1981], Baumol, Panzar and Willig [1983], and Innes and Sexton [1993, 1994], who emphasize the role of long-term contracts. In this class of models, potential entrants have the ability to offer long-term contracts to customers

\footnotetext{
${ }^{1}$ For example, in the ongoing Microsoft antitrust case (United States v. Microsoft, Civil Case 98-1232 [1998]), one of the charges brought against Microsoft is that it ties sales of its Internet Explorer to PC operating system sales. It, thus, allegedly uses its PC operating systems monopoly as the locomotive to pull its Explorer through the Internet browsers' market.

Microsoft claims that, among other things, it does not have monopoly power in the PC operating systems industry. Its extremely high market share does not translate into market power because the company faces the threat of potential competition. As Schmalensee [1999], one of the expert witnesses of Microsoft, pointed out, "Of far greater concern to Microsoft is the competition from new and emerging technologies, some of which are currently visible and others of which certainly are not. This array of known, emerging, and wholly unknown competitors places enormous pressure on Microsoft to price competitively and innovate aggressively."

${ }^{2}$ Civil Aeronautics Board, Hearings for Proposed Rulemaking - Airline Computer Reservation Systems, EDR - 466 [1983]. During the hearings, United Airlines claimed that airline and computer reservation systems markets are contestable. Yet these industries exhibit mainly spot market transactions. See United Airlines [1983]. Also, in Microsoft (supra note 1), the PC operating systems market typically exhibits short-term transactions. The 1994 Consent Decree prohibits Microsoft from offering long-term contracts (contracts with duration longer than one year) for operating systems (see U.S. District Court [1994]).
} 
before entering the market. ${ }^{3}$ The length of these contracts is equal to the life span of the sunk investment. Then, the industry is perfectly contestable because the contracts insulate potential entrants from post-entry competition with the incumbent, thereby allowing entrants to recover their sunk costs. The incumbent monopolist is, thus, induced to offer contract prices equal to average cost because, otherwise, it will be undercut by potential entrants.

Baumol, Panzar and Willig [1983] point out that even when potential entrants offer contracts with terms shorter than the life span of the sunk investment, the industry can be "imperfectly contestable". Provided that the term of contracts is sufficiently long, the incumbent is induced to charge an equilibrium contract price that is restrained below the monopoly price. Imperfect contestability approaches perfect contestability in the limit as the length of contracts approaches the life span of the sunk investment.

Notably, the existing models imply that an industry with sunk costs can be contestable only when equilibrium transactions take the form of long-term contracts. The length of these contracts must equal or approach the life span of the sunk investment. In this vein, critics point out that the concept of contestability is applicable only to a narrow range of industries (e.g., Schwartz and Reynolds [1983]). Indeed, in many monopolized industries with sunk costs, we observe shorter-term transactions (e.g., spot market transactions) rather than the type of very long-term contracts portrayed by the existing literature. $^{5}$

This paper shows that the concept of contestability may be relevant to a much broader set of industries than the one implied by the existing models. An industry with sunk costs may be contestable even if no long-term contracts are actually offered in equilibrium. The mere threat of contract offers by potential entrants can discipline the incumbent monopolist and lead to low spot market prices - or, more generally, to low short-term market prices. In these circumstances, the long-term contract market is latent,

\footnotetext{
${ }^{3}$ Innes and Sexton [1994] point out that this assumption is applicable to several industries. To introduce competition into the contracting process, customers have the incentive to seek out and find potential entrants, even if the latter do not exist initially.

${ }^{4}$ Baumol, Panzar and Willig [1983] use the term "almost contestable", rather than "imperfectly contestable".

${ }^{5}$ For example, Schwartz and Reynolds [1983] point out that the type of long-term contracts required for contestability is likely to be infeasible in many industries. In many cases, entrants do not have the ability to offer long-term contracts to customers before entering the market.
} 
in the sense that no long-term agreements are actually observed in equilibrium. Contestability stems from the potential ability of suppliers to offer long-term contracts, rather than the existence of actual contract offers.

There are two crucial ingredients in the model. The first is the existence of an infinite time horizon; the basic game is repeated an infinite number of times. The second important ingredient is the difference in transaction costs between short-term and longterm transactions. As Williamson [1975, 1979] and Klein, Crawford and Alchian [1978] point out, transactions of different length entail different costs. Short-term transactions may be either more costly or less costly than long-term transactions.

It is shown that when the spot market entails lower transaction costs than the long-term contract market, the industry can be contestable (imperfectly) even if it exhibits spot market transactions in equilibrium. Specifically, there exists a class of subgame perfect outcomes in which the monopolist sells only on the spot market (rather than through long-term contracts) and charges low spot market prices along the equilibrium path to maintain a reputation for defensive pricing and prevent customers from resorting to long-term contracts. Customers, on the other hand, also show goodwill and refrain from long-term contracts along the equilibrium path in order to reassure the monopolist that it will be rewarded if it continues charging low spot market prices in the future. Implicit cooperation between the incumbent monopolist and its customers, thus, becomes a substitute for long-term contracts as a means to guarantee low prices. These spot outcomes Pareto dominate the contract equilibrium: the contracting costs that are saved are distributed between the incumbent supplier and its customers.

Of course, an industry exhibiting short-term transactions is not necessarily contestable; the crucial test for contestability is the level of transaction costs in the latent contract market. When, as the existing literature implies, the latent contract market is a nonentity, the concept of contestability is inapplicable to the industry. When, on the other hand, a latent contract market exists (i.e., transaction costs in the latent contract market are not prohibitive), the industry may be contestable.

The reasoning is exactly the same if the potential entrant in the latent contract market is the customers themselves. Specifically, the customers can form a coalition and 
integrate vertically by entering the supplier's industry. ${ }^{6}$ In these circumstances, collective vertical integration amounts to a long-term contract: customers will be able buy the product at a price equal to marginal cost during the entire life of the sunk investment, thereby recovering their sunk investment through lower purchasing costs.

At the empirical level, the model is mainly applicable to industries in which the potential costs of long-term contracting (or, of collective vertical integration) are not prohibitive. The railroad industry is a good example. In general, the railroad industry exhibits short-term transactions in equilibrium. Although some customers have long-term contracts (e.g., 20-year contracts) with their carriers, the duration of these contracts is short relative to the life span of rail lines. ${ }^{7}$ Also, the railroad industry has very significant sunk costs. ${ }^{8}$

By some estimates, 90 percent of rail customers in the United States are captive to a single railroad, and some complain that the freight rates they are paying are 20 percent to 30 percent higher than in a competitive market (Machalaba [1998]). Furthermore, there are very serious complaints about the reliability of delivery times of railroads. In the recent years, some customers have responded to these rate and service disputes by integrating vertically and building their own connecting tracks to reach the lines of rival railroads. Once a customer gains access to the lines of rival railroads, it can reap the benefits of competition and receive lower freight rates and better service by playing the railroads against each other. ${ }^{9}$

At first, railroad companies did not take their customers' plans to build connecting tracks seriously, dismissing them as unfounded threats to drive down freight rates. Indeed, building track turned out to be a daunting task for some railroad customers. It cost Houston Lighting \& Power, for example, \$24 million to build a 10-mile connecting line (Machalaba [1998]). However, railroad companies soon realized that

\footnotetext{
${ }^{6}$ Innes and Sexton [1993] examine in detail the mechanics of customer coalitions.

${ }^{7}$ With proper maintenance, railroad corridors have very long life spans. For example, many of the railroad corridors that were assembled in the mid-nineteenth century are still in operation. See Sennewald [1998].

${ }^{8}$ The amount recovered when a railroad corridor is abandoned is very low compared with the amount that would be required to reassemble the corridor (e.g., Sennewald [1998]).

${ }^{9}$ For example, Houston Lighting \& Power, a utility that was a captive customer of Burlington Northern Santa Fe, built a 10-mile connecting line to reach the lines of Union Pacific, a rival of Burlington. Also, Southern, a captive customer of Norfolk Southern, is currently building four new connecting lines to reach the lines of Norfolk Southern's competitors. Although Southern will spend \$40 million on its four lines, it says it has already recouped more than that in lower freight costs. See Machalaba [1998].
} 
although the construction cost of connecting tracks was high, it was not prohibitive. So far, more than 12 new connecting lines have been completed and several more seem possible. Having realized that the threat of vertical integration is credible, railroad companies are now trying to prevent customers from building connecting tracks by offering lower rates and better service. As Machalaba [1998] notes, “... the main obstacle to many upstarts is the rail giants themselves, which contend that their service isn't so bad, note that their rates have dropped and ..." In these circumstances, the mere threat of customers to resort to the latent contract market may discipline rail carriers.

Still, the railroad industry also demonstrates the limitations of the concept of contestability. Small customers that are not in a position to operate connecting lines are less successful in dealing with railroad companies (Machalaba [1998]). It appears that these customers are unlikely to enjoy lower rates and better service since their transaction costs in the latent contract market are prohibitive.

The concept of contestability is introduced by the seminal study of Baumol, Panzar and Willig [1982], who focus on industries without sunk costs. Baumol, Panzar and Willig demonstrate that as long as there are no sunk costs, potential competition can be very effective in disciplining an incumbent monopolist. Baumol, Panzar and Willig portrait an industry in which entry and exit are costless, and prices adjust more slowly than decisions about entry. Then, the possibility of "hit-and-run" entry by potential competitors prevents the monopolist from charging a price above average cost. ${ }^{10}$ Unlike Baumol, Panzar and Willig, who focus on industries without sunk costs, the present paper examines the conditions under which an industry may be contestable in the presence of sunk costs.

The literature on market contestability is extensive. For example, Appelbaum and Lim [1985] suggest that the degree of market contestability may be endogenously determined by the choice of pre-commitments. Maskin and Tirole [1988] formulate an infinite-horizon model of quantity competition. They show that when firms commit to quantities for a period equal to the life span of the sunk investment, the incumbent monopolist will choose the entry-deterring quantity in equilibrium, which is higher than

\footnotetext{
${ }^{10}$ Tirole [1988] criticizes this version of contestability theory on the grounds that in several industries, prices often seem to adjust more rapidly than decisions about entry.
} 
the monopoly quantity. Fernandez and Rasmusen [1993] extend the theory of contestability to include informational imperfections. ${ }^{11}$

The paper consists of seven sections. Section 2 presents the basic one-period model, and section 3 the infinitely repeated model. Section 4 solves for the equilibrium of the infinitely repeated game. Section 5 examines the extent to which the repeated game leads to market contestability. Section 6 discusses an extension of the model with alternating incumbents. Finally, section 7 suggests some conclusions.

\section{THE BASIC ONE-PERIOD MODEL}

Two suppliers, $\mathrm{M}$ and $\mathrm{E}$, can provide a homogeneous product to $\mathrm{n}$ identical customers. The suppliers have identical technologies and face a fixed cost F, as well as a constant marginal cost c. Fixed investment $\mathrm{F}$ is sunk and cannot be recouped in the case of exit; once a supplier makes the investment $F$, it stays in the market for the entire game. $M$ is the incumbent monopolist, in that it decides first whether to enter the market. $\mathrm{E}$ is the potential entrant. Customers have unit demands; each consumes either one or zero unit of the product. Also, a customer derives a surplus from consumption equal to R.

There are two markets for the product, the spot and the contract market. The spot market occurs after production takes place. Suppliers have their products on hand, and the goods are delivered immediately - on the spot. The contract market, on the other hand, occurs before E decides whether to enter and production takes place. The products are not physically present but, instead, are bought and sold via contracts that specify a future delivery date and fix a price. Buying on the spot market is buying instantaneously, while on the contract market, it is over the long term.

A spot market transaction between a supplier and a customer entails a cost $z^{S}$. The transaction cost is borne by the supplier. It is assumed that $\mathrm{n}\left(\mathrm{R}-\mathrm{c}-\mathrm{z}^{\mathrm{S}}\right) \geq \mathrm{F}$; the social value of the product in the spot market is higher than its cost. Also, before E decides whether to enter, both $\mathrm{M}$ and $\mathrm{E}$ have the opportunity to offer long-term contracts to

\footnotetext{
${ }^{11}$ In a different vein, the theory of limit pricing also shows that an incumbent monopolist may be induced to lower its price below the monopoly level (yet not necessarily to the average cost level) to prevent potential entry (e.g., Milgrom and Roberts [1982], Katz [1987]). When potential entrants do not know the cost of the incumbent, low prices may discourage entry by conveying the information that the incumbent has a low cost. Depending on the specific circumstances, limit pricing can either raise or lower social welfare. Although it may lead to lower pre-entry prices, it may also discourage socially efficient entry.
} 
customers. If a customer signs a long-term contract, it has the obligation to buy one unit of the product from the corresponding supplier at a price $\mathrm{w}^{\mathrm{M}}$ (if the supplier is $\mathrm{M}$ ), or $\mathrm{w}^{\mathrm{E}}$ (if the supplier is E). Moreover, the supplier has the obligation to sell one unit of the product to the customer at the specified price. A long-term contract between a supplier and a customer entails a cost $z^{C}$. The transaction cost is borne by the supplier. It is assumed that the contracting cost is not prohibitive, i.e., $n\left(R-c-z^{C}\right) \geq F$; the social value of the product in the contract market is higher than its cost.

$\mathrm{z}^{\mathrm{S}}$ may be either higher or lower than $\mathrm{z}^{\mathrm{C}}$, i.e., spot market transactions may be either more costly or less costly than contract market transactions. A discussion of the factors that determine the optimal transaction length is provided, for example, by Williamson [1975, 1979] and Klein, Crawford and Alchian [1978].

For simplicity, it is assumed that a supplier cannot practice price discrimination; it has to offer the same spot or contract price to all customers. Also, for simplicity, I assume that trade between suppliers cannot take place. Finally, a contract is conditional upon the presence of the supplier in the market. If E has not entered, its contracts are not valid, and there are no contractual obligations for either $\mathrm{E}$ or its customers.

We have a four-stage game:

Stage 1: $\mathrm{M}$ decides whether to make the fixed investment $\mathrm{F}$ and enter the market.

Stage 2: If $\mathrm{M}$ has entered, $\mathrm{M}$ and $\mathrm{E}$ have the opportunity to sell their products on the contract market by offering long-term contracts to customers. ${ }^{12}$ The latter decide whether to accept sequentially: Customer 1 first makes its contract decisions, then customer 2, and so on. ${ }^{13}$

Stage 3: E decides whether to make the fixed investment $\mathrm{F}$ and enter the market.

\footnotetext{
${ }^{12}$ If $\mathrm{M}$ has not entered, $\mathrm{M}$ and $\mathrm{E}$ have no reason to offer contracts to customers.

${ }^{13}$ The assumption that customers make their contract decisions sequentially, rather than simultaneously, implies that E's contract offers are always credible. This assumption is made for simplicity; customers can implicitly coordinate their contract decisions to their mutual betterment. If buyers, on the other hand, decided simultaneously, there would be an additional subgame perfect equilibrium in which E would not have the ability to make credible contract offers. Specifically, E's contracts are valid only if it enters the market in stage 3. Otherwise, there are no contractual obligations for either $E$ or its customers. In a game of simultaneous acceptance decisions, E's contract offers are credible only if customers believe that E will elicit contract acceptance by a sufficient number of customers to cover its fixed cost of entry. If a customer believes that the others will not sign E's contracts, then it will not sign either, even when E offers a lower contract price than M.
} 
Stage 4: Production and spot market pricing take place. The customers that already have contracts buy from their supplier at the specified contract price.

The structure of the game is similar to the one suggested informally by Baumol, Panzar and Willig [1983], and modeled formally by Innes and Sexton [1993, 1994]. In this class of models, potential entrants are able to offer contracts while they are still out of the market. ${ }^{14}$

The following tie-breaking conventions are adopted:

(a) If $\mathrm{M}$, or $\mathrm{E}$ is indifferent between entering and not, it will enter.

(b) If a customer is indifferent between signing M's and E's contract, it will sign the contract of $\mathrm{M}$.

(c) If a customer is indifferent between signing a contract (either M's or E's) in stage 1 and waiting for the spot market, it will choose the most efficient transaction length: The customer will sign the contract if $\mathrm{z}^{\mathrm{S}} \geq \mathrm{z}^{\mathrm{C}}$, and refuse to sign if $\mathrm{z}^{\mathrm{S}}<\mathrm{z}^{\mathrm{C}}$.

To solve for the equilibrium of this simple game, I proceed by backward induction. If no contracts are signed in stage 2 , no entry will take place in stage 3 . Then, in stage $4, \mathrm{M}$ will set its price equal to $\mathrm{R}$ and will extract all customer surplus. ${ }^{15}$ Thus, in stage 2, E has the incentive to offer favorable contract terms in order to convince customers to sign its contracts. $\mathrm{M}$, on the other hand, will try to prevent customers from entering into agreements with $\mathrm{E}$ by offering its own contracts. Competition in contract offers leads to average cost pricing in the contract market. In equilibrium, all customers sign M's contracts with a price $\mathrm{w}^{\mathrm{M}^{*}}=\mathrm{F} / \mathrm{n}+\mathrm{c}+\mathrm{z}^{\mathrm{C}}$. Total customer welfare is equal to $\mathrm{n}(\mathrm{R}$ $\left.-\mathrm{c}-\mathrm{z}^{\mathrm{C}}\right)-\mathrm{F}$.

Proposition 1: In the one-period game, all customers sign the long-term contracts of $\mathrm{M}$. The equilibrium contract price is equal to average cost in the contract market $\left(\mathrm{w}^{\mathrm{M}^{*}}=\mathrm{F} / \mathrm{n}\right.$ $+\mathrm{c}+\mathrm{z}^{\mathrm{C}}$ ).

\footnotetext{
${ }^{14}$ Also, notice that although M moves first, it has no reason to offer contracts to customers before stage 2 . Customers would not accept a contract price higher than the one they expect to face in stage 2.

${ }^{15}$ Notice that if no contracts are signed in stage 2, E will decide not to enter in stage 3. If E entered, price competition in stage 4 would lead to an equilibrium price equal to $\mathrm{c}+\mathrm{z}^{\mathrm{S}}$, and thus $\mathrm{E}$ would not be able to recover its fixed investment $\mathrm{F}$.
} 
Proposition 1 is also stated informally by Baumol, Panzar and Willig [1983], and derived formally by Innes and Sexton [1993, 1994]. The only difference is the absence of contract and spot market transaction costs in these articles.

Customers sign M's contracts regardless of whether $z^{S}$ is higher or lower than $z^{C}$. Thus, customers buy on the contract market even when the spot market is more efficient, i.e., even when $\mathrm{z}^{\mathrm{S}}<\mathrm{z}^{\mathrm{C}}$. In this case, although contracts raise customer welfare by guaranteeing low prices to customers (in the absence of contracts, customers would have to pay a spot market price R), they also lower total economic welfare by $n\left(z^{C}-z^{S}\right)$.

The industry is perfectly contestable only when $\mathrm{z}^{\mathrm{S}} \geq \mathrm{z}^{\mathrm{C}}$. In this case, the equilibrium industry configuration is sustainable; E cannot make a profit taking M's equilibrium price $\left(\mathrm{F} / \mathrm{n}+\mathrm{c}+\mathrm{z}^{\mathrm{C}}\right)$ as given. ${ }^{16}$ On the other hand, when $\mathrm{z}^{\mathrm{S}}<\mathrm{z}^{\mathrm{C}}$ the industry is not perfectly contestable; $\mathrm{E}$ can make a profit in the spot market taking M's equilibrium price $\left(\mathrm{F} / \mathrm{n}+\mathrm{c}+\mathrm{z}^{\mathrm{C}}\right)$ as given.

Still, even when $z^{S}<z^{C}$, the industry is "imperfectly contestable" in the sense that competition in contract offers restrains M's prices; M's equilibrium price is below the monopoly price $\mathrm{R}\left(\mathrm{F} / \mathrm{n}+\mathrm{c}+\mathrm{z}^{\mathrm{C}} \leq \mathrm{R}\right)$. Imperfect contestability approaches perfect contestability in the limit as $\mathrm{z}^{\mathrm{C}}$ approaches $\mathrm{z}^{\mathrm{S}}$ from the right side. ${ }^{17}$

Proposition 2: The industry is perfectly contestable only when $z^{\mathrm{S}} \geq \mathrm{z}^{\mathrm{C}}$. When $\mathrm{z}^{\mathrm{S}}<\mathrm{z}^{\mathrm{C}}$, the industry is imperfectly contestable in the sense that M's equilibrium price is restrained below the monopoly price $\mathrm{R}\left(\mathrm{F} / \mathrm{n}+\mathrm{c}+\mathrm{z}^{\mathrm{C}} \leq \mathrm{R}\right)$. Imperfect contestability approaches perfect contestability in the limit as $\mathrm{z}^{\mathrm{C}}$ approaches $\mathrm{z}^{\mathrm{S}}$ from the right side.

So far we have assumed that the contracting $\operatorname{cost} \mathrm{z}^{\mathrm{C}}$ is not prohibitive, i.e., $\mathrm{n}(\mathrm{R}-\mathrm{c}$ $\left.-\mathrm{z}^{\mathrm{C}}\right) \geq \mathrm{F}$. When $\mathrm{z}^{\mathrm{C}}$ is prohibitive $\left(\mathrm{n}\left(\mathrm{R}-\mathrm{c}-\mathrm{z}^{\mathrm{C}}\right)<\mathrm{F}\right)$, on the other hand, the industry is neither perfectly nor imperfectly contestable. In this case, $M$ sets its price in the spot market equal to $\mathrm{R}$ and extracts all customer surplus.

\footnotetext{
${ }^{16}$ According to Baumol, Panzar and Willig [1982], an industry configuration is sustainable if no entrant can make a profit taking the incumbent's price as given. A perfectly contestable market is one in which any equilibrium industry configuration must be sustainable.

${ }^{17}$ When $z^{C}>z^{S}$, the deleterious effect of the contracting $\operatorname{cost} z^{C}$ on contestability behaves continuously. If $\mathrm{z}^{\mathrm{C}}$ is not much higher than $\mathrm{z}^{\mathrm{S}}$, the industry is almost perfectly contestable.
} 
Proposition 3: When the contracting cost $\mathrm{z}^{\mathrm{C}}$ is prohibitive $\left(\mathrm{n}\left(\mathrm{R}-\mathrm{c}-\mathrm{z}^{\mathrm{C}}\right)<\mathrm{F}\right)$, the industry is not contestable. In this case, all transactions take place in the spot market, and $\mathrm{M}$ charges the monopoly price $\mathrm{R}$.

It follows that the level of the contracting $\operatorname{cost} \mathrm{z}^{\mathrm{C}}$ is a crucial test for contestability. When $\mathrm{z}^{\mathrm{C}}$ is not prohibitive, competition in contract offers between $\mathrm{M}$ and E restrains M's prices below $R$. The industry is perfectly (if $z^{S} \geq z^{C}$ ), or imperfectly (if $z^{S}$ $<\mathrm{z}^{\mathrm{C}}$ ) contestable. When $\mathrm{z}^{\mathrm{C}}$ is prohibitive, on the other hand, M's prices are not restrained at all; $\mathrm{M}$ sets its price equal to $\mathrm{R}$.

Propositions 1, 2 and 3 would also hold in a finitely repeated game. According to the Chainstore Paradox, the equilibrium of a finitely repeated game is identical to that of the one-period game (e.g., see Rasmusen [1994]).

\section{INFINITELY REPEATED GAME}

Propositions 1, 2 and 3 state that when the contracting $\operatorname{cost} \mathrm{z}^{\mathrm{C}}$ is not prohibitive, equilibrium transactions take place in the contract market, and the industry is contestable (perfectly or imperfectly). When $\mathrm{Z}^{\mathrm{C}}$ is prohibitive, on the other hand, equilibrium transactions take place in the spot market, and $\mathrm{M}$ charges its monopoly price $\mathrm{R}$. It follows that an industry in which transactions take place in the spot market cannot be contestable. In this vein, critics of the theory of contestability point out that since many industries exhibit spot market, rather than contract market, transactions in equilibrium, the applicability of contestability theory is limited. ${ }^{18}$

However, it will now be shown that contestability may be applicable to a much wider range of industries than those suggested by the existing literature. An industry may be imperfectly contestable even if equilibrium transactions take place in the spot market. In particular, the basic model will be extended to allow for an infinite time horizon.

\footnotetext{
${ }^{18}$ Critics of the theory of contestability point out that the level of $\mathrm{z}^{\mathrm{C}}$ is often prohibitive. In many cases, for example, E does not have the ability to offer contracts to customers before entering the market (e.g., Schwartz and Reynolds [1983]). The assumption that entrants cannot offer contracts to customers while they are still out of the market is also made by several articles in the contract theory literature (e.g., Rasmusen, Ramseyer and Wiley [1991], Stefanadis [1998]).
} 
Let us consider an extension of the basic model in which there is an infinite number of periods: $\mathrm{t}=1,2, \ldots$ As before, suppliers $\mathrm{M}$ and $\mathrm{E}$ have a sunk cost $\mathrm{F}$ and a constant marginal cost $\mathrm{c}$. Investment $\mathrm{F}$ has a one-period life span, and $\mathrm{M}$ has the opportunity to move first and renew $\mathrm{F}$ at the beginning of each period. ${ }^{19}$ In section 6 , an extension of the model will be examined in which $\mathrm{M}$ moves first at the beginning of a period with probability $\mathrm{k}$, while $\mathrm{E}$ moves first with probability $1-\mathrm{k} .{ }^{20}$ As we will see, the conclusions will be basically the same.

In each period, customers have unit demands; each consumes either zero or one unit of the product. Also, in each period, a customer derives a surplus from consumption equal to $\mathrm{R}$. The discount factor is $*=1 /(1+\mathrm{r})$, where $\mathrm{r}$ is the interest rate $(0<*<1)$.

As in the basic game, before $\mathrm{E}$ decides whether to enter the market in a period, both $\mathrm{M}$ and $\mathrm{E}$ have the opportunity to offer long-term contracts to customers. The length of a contract is equal to the life span of the fixed investment $\mathrm{F}$, i.e., each contract has a one-period time length. Transactions costs in the spot and the contract market are not prohibitive, i.e., $n\left(R-c-z^{S}\right) \geq F$ and $n\left(R-c-z^{C}\right) \geq F$.

We have the following game:

Stage 1: M decides whether to enter the market.

Stage 2: If $M$ has entered, $M$ and $E$ have the opportunity to offer long-term contracts to customers. ${ }^{21}$ The latter decide whether to accept sequentially: Customer 1 first makes its contract decisions, then customer 2 , and so on. ${ }^{22}$

Stage 3: E decides whether to enter the market.

Stage 4: Production and spot market pricing take place. The customers that already have contracts buy from their supplier at the specified contract price.

Stage 5: Next period starts. The game goes back to stage 1 and repeats. ${ }^{23}$

The same tie-breaking conventions as in the one-period game are adopted.

\footnotetext{
${ }^{19}$ Alternatively, we could think that fixed investment has a maintenance cost $\mathrm{F}$ in each period.

${ }^{20} \mathrm{M}$ and $\mathrm{E}$ never want to make the investment $\mathrm{F}$ simultaneously at the beginning of a period. Then, neither supplier will recover its fixed cost.

${ }^{21}$ Supra note 12.

${ }^{22}$ Supra note 13.

${ }^{23}$ Notice that the outcome of the game would be the same if there were a fixed probability 2 that the market "disappeared" (because of the introduction of a superior product or a change in tastes, for example)
} 


\section{EQUILIBRIUM OF THE INFINITELY REPEATED GAME}

According to the folk theorem, the repeated game has a wide range of subgame perfect equilibria, including a large number with different prices and lengths of transactions through time, like (contracts, contracts, spot transactions, contracts, spot transactions, spot transactions, ....). ${ }^{24}$ The repeated game also leads to a large number of collusive outcomes in which each supplier stays out of the market or charges high prices in certain periods to allow its rival to raise its profits. However, if we confine ourselves to purestrategy equilibria with a stationary outcome of constant prices, constant length of transactions, and identical transacting parties (i.e., the same supplier selling to customers throughout the game), then the two outcomes are "contract transactions" and "spot transactions". It will be shown that when the spot market is more efficient $\left(\mathrm{z}^{\mathrm{S}}<\mathrm{z}^{\mathrm{C}}\right)$, there exists a class of spot equilibria that Pareto dominate the contract equilibrium.

\subsection{Contract Equilibrium}

Contract transactions is always an equilibrium outcome because it is the equilibrium of the one-period game. ${ }^{25}$ Specifically, consider the strategy in which $\mathrm{M}$ sets its spot market price in stage 4 equal to $\mathrm{R}$ if it has monopoly power in that period. Otherwise, if $\mathrm{E}$ has entered, the two suppliers compete in prices, and $\mathrm{M}$ sets its spot market price equal to $\mathrm{c}+$ $z^{S}$. Also, in stage 2, M and E offer contracts to customers with a price $w^{M}=w^{E}=F / n+c$ $+\mathrm{z}^{\mathrm{C}}$, i.e., a price equal to average cost. This strategy profile is a subgame perfect equilibrium. All customers sign M's contracts and buy the product at a price equal to $\mathrm{w}^{\mathrm{M}}$ in each period. Customers know that if they do not sign a contact in stage 1, they will have to pay a spot price $\mathrm{R}$ in stage 4 since $\mathrm{E}$ will stay out of the market. Customer surplus is equal to $n\left(R-c-z^{C}\right)-F$ in each period, while the profit of $M$ is zero.

As in the one-period game, customers buy on the contract market even when the spot market is more efficient, i.e., even when $z^{S}<z^{C}$. When $z^{S} \geq z^{C}$, the industry is perfectly contestable, while when $\mathrm{z}^{\mathrm{S}}<\mathrm{z}^{\mathrm{C}}$, it is imperfectly contestable.

at the end of each period. Then, the only difference would be that the discount factor would be equal to $*=$ $(1-2) /(1+r)$ (for example, see Tirole [1988], Rasmusen [1994]).

${ }^{24}$ For an extensive discussion of the folk theorem, see, for example, Tirole [1988], Fudenberg and Tirole [1991], Rasmusen [1994].

${ }_{25}$ The equilibrium of the one-period game is always one of the equilibria of the infinitely repeated game. See, for example, Fudenberg and Tirole [1991]. 
Notice that there is a bootstrap aspect in the equilibrium. Even when the contract market entails higher transaction costs than the spot market, customers seek the security of long-term contracts because they believe that $\mathrm{M}$ will behave aggressively in the spot market and charge a price equal to R. M, on the other hand, behaves aggressively in the spot market because it believes that there is no way to convince customers to show goodwill and enter the spot market without having signed long-term contracts. No matter how M behaves, customers will seek the security of long-term contracts from then on.

\subsection{Spot Equilibrium}

If the spot market is more efficient than the contract market $\left(\mathrm{z}^{\mathrm{S}}<\mathrm{z}^{\mathrm{C}}\right)$ and the discount factor $*$ is high enough (i.e., the players are patient enough), spot transactions is also an equilibrium outcome. Consider, for example, the following strategy profile:

Customers. If $\mathrm{M}$ has entered the market in stage 1, customers base their decisions on M's "reputation". Reputation in period t is determined by the spot market prices that M chose in previous periods. If M's spot market price has not been strictly higher than $\mathrm{p}^{\mathrm{H}}=$ $\mathrm{c}+\mathrm{F} / \mathrm{n}+\mathrm{z}^{\mathrm{C}}$, i.e., M's average production plus contracting cost, in the previous periods, M has a reputation for "defensive pricing". Otherwise, if M's spot market price has been strictly above $\mathrm{p}^{\mathrm{H}}$ in at least one period, $\mathrm{M}$ has a reputation for "aggressive pricing". As long as $\mathrm{M}$ has a reputation for defensive pricing, customers refuse to sign any long-term contracts unless these contracts offer a price strictly lower than $\mathrm{p}^{\mathrm{H}}$. If, on the other hand, $\mathrm{M}$ has a reputation for being aggressive, a customer signs the long-term contract with the lowest price (no matter whether this price is above or below $\mathrm{p}^{\mathrm{H}}$ ) that is offered in stage 2 . Customers have a favorable prior: $\mathrm{M}$ has a reputation for being defensive when it first enters the market.

Supplier M. M enters the market in each period. When $M$ is the only supplier in the market, it sets its spot market price equal to $\mathrm{p}^{\mathrm{H}}$. However, if $\mathrm{M}$ ever deviates from this strategy by charging a spot market price higher than $\mathrm{p}^{\mathrm{H}}$, it will keep setting its spot market price equal to $\mathrm{R}$ from then on whenever it has the opportunity (that is, in all subsequent periods in which $\mathrm{M}$ maintains a monopoly position). When $\mathrm{E}$ has also entered the market, $\mathrm{M}$ sets its spot market equal to $\mathrm{c}+\mathrm{z}^{\mathrm{S}}$. 
$\mathrm{M}$ does not offer long-term contracts to customers in stage 1 as long as its spot prices in previous periods have not been above $\mathrm{p}^{\mathrm{H}}$. If, on the other hand, M's spot price has been above $\mathrm{p}^{\mathrm{H}}$ in at least one period before, $\mathrm{M}$ will keep offering long-term contracts to customers in stage 1 with a price $\mathrm{w}^{\mathrm{M}}=\mathrm{c}+\mathrm{F} / \mathrm{n}+\mathrm{z}^{\mathrm{C}}$ from then on.

Supplier E. E does not offer any long-term contracts in stage 2 as long as $M$ has a reputation among customers for being defensive. If, on the other hand, $\mathrm{M}$ has a reputation for being aggressive, E will keep offering long-term contracts to customers in stage 1 with a price $\mathrm{w}^{\mathrm{E}}=\mathrm{c}+\mathrm{F} / \mathrm{n}+\mathrm{z}^{\mathrm{C}}$ from then on.

This strategy profile is a subgame perfect equilibrium. Along the equilibrium path, suppliers do not offer any long-term contracts, and customers always buy on the spot market from $\mathrm{M}$ at a price $\mathrm{p}^{\mathrm{H}}$. E stays out of the market. In particular, if $\mathrm{M}$ follows its prescribed strategy, it obtains an inter-temporal profit of

$$
\begin{gathered}
\mathrm{n}\left(1+*+*^{2}+\ldots\right)\left(\mathrm{c}+\mathrm{F} / \mathrm{n}+\mathrm{z}^{\mathrm{C}}-\mathrm{c}-\mathrm{z}^{\mathrm{S}}-\mathrm{F} / \mathrm{n}\right)= \\
\mathrm{n}\left(\mathrm{z}^{\mathrm{C}}-\mathrm{z}^{\mathrm{S}}\right) /(1-*) .
\end{gathered}
$$

If, instead, $\mathrm{M}$ were to deviate and charge a spot market price $\mathrm{R}$ in a period, it would obtain a profit of $n\left(R-c-z^{S}\right)-F$ in the deviation period and a profit of zero thereafter. Hence a necessary condition for Nash equilibrium is that the "fly by night" strategy is unprofitable for M:

$$
\mathrm{n}\left(\mathrm{z}^{\mathrm{C}}-\mathrm{z}^{\mathrm{S}}\right) /(1-*) \geq \mathrm{n}\left(\mathrm{R}-\mathrm{c}-\mathrm{z}^{\mathrm{S}}\right)-\mathrm{F} .
$$

This inequality is satisfied for a range of $*$ less than 1 because it holds strictly at the $*=$ 1 limit.

Also, a customer's prescribed strategy leads to a surplus $\mathrm{R}-\mathrm{c}-\mathrm{F} / \mathrm{n}-\mathrm{z}^{\mathrm{C}}$ per period. If the customer were to deviate and choose to sign an above- $\mathrm{p}^{\mathrm{H}}$ or equal-to- $\mathrm{p}^{\mathrm{H}}$ contract, it would not be able to increase its surplus. Thus, a customer has no incentive to deviate.

Further, if $\mathrm{M}$ and $\mathrm{E}$ were to deviate and offer long-term contracts in stage 1 given that $\mathrm{M}$ has a reputation for defensive pricing, they would not be able to increase their 
profits. No customer would sign a contract with a price equal to or above $\mathrm{p}^{\mathrm{H}}-$ i.e., equal to or above average cost in the contract market. Thus, $\mathrm{M}$ and $\mathrm{E}$ have no incentive to deviate and make contract offers to customers.

To check that the strategy profile is subgame perfect, notice that in every subgame off the equilibrium path the players choose either the one-period equilibrium strategies, or the one-period off-equilibrium subgame strategies forever, which is a Nash equilibrium.

In this spot equilibrium, long-term contracts are not necessary to guarantee low prices; no long-term contracts are offered by suppliers along the equilibrium path. Instead, M charges low spot market prices voluntarily to prevent customers from signing costly long-term contracts in the future. M's prices are kept sufficiently low, so that customers would have nothing to gain by resorting to long-term contracts. In this outcome, implicit cooperation between $\mathrm{M}$ and its customers replaces contracting as a means to secure low prices.

Finally, notice the bootstrap aspect of this equilibrium. Reputation matters only because players believe it matters. Along the equilibrium path, $\mathrm{M}$ and its customers follow a strategy of goodwill. Each player believes that by showing goodwill, it will convince the other players to follow suit.

\subsection{Other Spot Equilibria}

In the previous spot equilibrium, the entire transaction $\operatorname{cost} n\left(\mathrm{z}^{\mathrm{C}}-\mathrm{z}^{\mathrm{S}}\right)$ that was saved in each period was distributed to $\mathrm{M}$. However, there is a wide range of spot equilibria, representing different distributions of the cost $n\left(z^{C}-z^{S}\right)$ that is saved between $M$ and its customers.

To see this, notice that the strategy profile of the previous section is still a subgame perfect equilibrium if $\mathrm{p}^{\mathrm{H}}$ is defined as $\mathrm{c}+\mathrm{F} / \mathrm{n}+\mathrm{x}$, where $\mathrm{x}$ is such that $\mathrm{x} \leq \mathrm{z}^{\mathrm{C}}$ and $n\left(x-z^{S}\right) /(1-*) \geq n\left(R-c-z^{S}\right)-F$. For this range of definitions of $p^{H}$, suppliers do not offer any long-term contracts along the equilibrium path, while $\mathrm{M}$ always sets its spot market price equal to $\mathrm{p}^{\mathrm{H}}$.

Specifically, since $n\left(x-z^{S}\right) /(1-*) \geq n\left(R-c-z^{S}\right)-F$, the fly by night strategy is unprofitable for $\mathrm{M}$. Also, since $\mathrm{x} \leq \mathrm{z}^{\mathrm{C}}$, a supplier cannot earn a profit by offering a 
contract with a price below $\mathrm{p}^{\mathrm{H}}$. Finally, as in section 4.2, to check that the strategy profile is subgame perfect, notice that in every subgame off the equilibrium path the players choose either the one-period equilibrium strategies, or the one-period off-equilibrium subgame strategies forever, which is a Nash equilibrium.

\subsection{Welfare}

The spot equilibria that we examined in sections 4.2 and 4.3 Pareto dominate the contract equilibrium: The transaction $\operatorname{cost} n\left(\mathrm{z}^{\mathrm{C}}-\mathrm{z}^{\mathrm{S}}\right)$ that is saved in each period is distributed between $\mathrm{M}$ and its customers. Specifically, customers and $\mathrm{M}$ are at least as well off in the spot outcomes: $\mathrm{n}(\mathrm{R}-\mathrm{c}-\mathrm{x})-\mathrm{F} \geq \mathrm{n}\left(\mathrm{R}-\mathrm{c}-\mathrm{z}^{\mathrm{C}}\right)-\mathrm{F}$ (customer welfare per period is weakly higher), and $n\left(x-z^{S}\right)>0$ (M's profit per period is higher). ${ }^{26}$ The spot equilibria lead to a total (customers' + suppliers') economic welfare equal to $n\left(R-c-z^{S}\right)-F$ per period, which is higher by $n\left(z^{C}-z^{S}\right) \geq 0$ than total economic welfare in the contract equilibrium. This is not surprising since the spot market is more efficient than the contract market.

Proposition 4: In the infinitely repeated game, when the spot market is more efficient than the contract market $\left(\mathrm{z}^{\mathrm{S}}<\mathrm{z}^{\mathrm{C}}\right)$, there exists a class of spot equilibria that Pareto dominate the contract equilibrium. In these spot equilibria, all customers buy in the spot market at a price $\mathrm{p}^{\mathrm{H}}$ that is weakly lower than average cost in the contract market $\left(\mathrm{p}^{\mathrm{H}} \leq \mathrm{c}\right.$ $+\mathrm{F} / \mathrm{n}+\mathrm{z}^{\mathrm{C}}$ ). No contracts are offered by suppliers along the equilibrium path.

The idea is that the mere threat of long-term contracting can induce $M$ to keep its prices low. In this class of spot outcomes, $\mathrm{M}$ follows a strategy of goodwill and charges low spot market prices along the equilibrium path to build a reputation for defensive pricing and prevent customers from resorting to long-term contracts in the future. Customers also show goodwill and refrain from long-term contracts along the equilibrium path in order to convince $M$ that it will be rewarded if it continues charging low spot market prices. Cooperation between $\mathrm{M}$ and its customers, thus, replaces explicit contracting and saves on the transaction costs of long-term agreements. These spot 
equilibria Pareto dominate the contract outcome because transaction costs are lower in the spot market $\left(\mathrm{z}^{\mathrm{S}}<\mathrm{z}^{\mathrm{C}}\right)$.

\section{MARKET CONTESTABILITY IN THE INFINITELY REPEATED GAME}

Unlike the one-period game, the infinitely repeated game shows that the industry can be contestable (imperfectly) even if equilibrium transactions take place in the spot market. Proposition 4 states that there is a class of spot equilibria in which the mere threat of long-term contracting disciplines $\mathrm{M}$ and restrains spot market prices below the monopoly price $\mathrm{R}\left(\mathrm{p}^{\mathrm{H}} \leq \mathrm{c}+\mathrm{F} / \mathrm{n}+\mathrm{z}^{\mathrm{C}} \leq \mathrm{R}\right)$.

It follows that when equilibrium transactions take place in the spot market, a latent contract market exists. In these circumstances, the crucial test for contestability is the level of transaction costs $z^{C}$ in the latent contract market. When $z^{C}$ is not prohibitive, the industry is imperfectly contestable; potential competition between $\mathrm{M}$ and $\mathrm{E}$ in the latent contract market restrains M's spot market prices below R. Imperfect contestability approaches perfect contestability in the limit as $\mathrm{z}^{\mathrm{C}}$ approaches $\mathrm{z}^{\mathrm{S}}$ from the right side.

Proposition 5: In the infinitely repeated game, an industry can be contestable (imperfectly) even if equilibrium transactions take place in the spot market. In this case, the crucial test for contestability is the level of transaction costs $\mathrm{z}^{\mathrm{C}}$ in the latent contract market.

When equilibrium transactions take place in the contract market, on the other hand, the industry is either perfectly (if $\mathrm{z}^{\mathrm{S}} \geq \mathrm{z}^{\mathrm{C}}$ ), or imperfectly (if $\mathrm{z}^{\mathrm{S}}<\mathrm{z}^{\mathrm{C}}$ ) contestable. In these circumstances, the crucial test for contestability is the level of transaction costs $z^{C}$ in the actual contract market (as in the one-period game).

\section{ALTERNATING INCUMBENTS}

So far it has been assumed that $\mathrm{M}$ has the opportunity to move first and renew $\mathrm{F}$ at the beginning of each period. I will now examine an extension of the infinitely repeated model in which incumbent suppliers can alternate. At the beginning of each period, $\mathrm{M}$

${ }^{26}$ Also, in any case, E earns a zero profit. 
moves first with probability $\mathrm{k}$, and $\mathrm{E}$ with probability $1-\mathrm{k}$, where $\mathrm{k}$ remains constant during the game. As we will see, the conclusions remain basically the same.

By following a similar procedure as before, we can see that contract transactions and spot transactions are still equilibrium outcomes. Specifically, we now have two separate games: each supplier builds its own reputation as an incumbent, and has its own trigger price, $\mathrm{p}^{\mathrm{HM}}$ (for $\mathrm{M}$ ) or $\mathrm{p}^{\mathrm{HE}}$ (for $\mathrm{E}$ ). In the spot equilibria, if a supplier deviates from its prescribed strategy, it will be punished by customers in all periods from then on in which it will be an incumbent. Since a supplier has a probability k (for M) or $1-\mathrm{k}$ (for E) to be an incumbent, $\mathrm{p}^{\mathrm{HM}}$ is defined as $\mathrm{c}+\mathrm{F} / \mathrm{n}+\mathrm{x}$, where $\mathrm{x}$ is such that $\mathrm{x} \leq \mathrm{z}^{\mathrm{C}}$ and $\mathrm{kn}(\mathrm{x}-$ $\left.\mathrm{z}^{\mathrm{S}}\right) /(1-*) \geq \mathrm{n}\left(\mathrm{R}-\mathrm{c}-\mathrm{z}^{\mathrm{S}}\right)-\mathrm{F}$, while $\mathrm{p}^{\mathrm{HE}}$ is defined as $\mathrm{c}+\mathrm{F} / \mathrm{n}+\mathrm{x}$, where $\mathrm{x}$ is such that $\mathrm{x} \leq$ $\mathrm{z}^{\mathrm{C}}$ and $(1-\mathrm{k}) \mathrm{n}\left(\mathrm{x}-\mathrm{z}^{\mathrm{S}}\right) /(1-*) \geq \mathrm{n}\left(\mathrm{R}-\mathrm{c}-\mathrm{z}^{\mathrm{S}}\right)-\mathrm{F}$.

\section{CONCLUSION}

The idea that an industry with sunk costs may be contestable even in the absence of longterm contracts is an argument that is incomprehensible in terms of economic theory yet seems persuasive to monopolists facing antitrust suits. This paper has developed a simple formal model that makes sense of the argument. To arrive at the monopolist's conclusion, two basic assumptions were made: the existence of an infinite time horizon, and the difference in transaction costs between short-term and long-term markets. It has been shown that there exists a class of subgame perfect equilibria in which all transactions take place in the spot market, and the mere threat of contract offers by potential entrants induces the monopolist to keep its spot market price low. In these circumstances, the crucial test for contestability is the level of transaction costs in the latent contract market.

Does the paper imply that, in practice, all or most of the markets are contestable? Certainly not. For one thing, when transaction costs in the contract market are prohibitive, the incumbent monopolist faces no potential competition and charges its monopoly price. Also, imperfect contestability does not necessarily lead to prices close to average cost, but only restrains equilibrium prices below the monopoly price. Imperfect contestability approaches perfect contestability only when the contracting cost is low.

Determining, then, the degree of contestability in an industry is an empirical matter. It may be that some industries are indeed contestable, while in others, 
contestability is a self-serving argument of those who would like to avoid antitrust action. In any case, expressing the monopolist's argument in a formal model can lead to a better appraisal of its strengths and weaknesses. The debate about contestability cannot be conclusive unless formal models incorporate the aspects of the world that defendants in antitrust cases consider important. 


\section{REFERENCES}

Appelbaum, Elie, and Chin Lim. "Contestable Markets under Uncertainty", RAND Journal of Economics, 16, Spring 1985, p. 28-40.

Baumol, William J., John C. Panzar, and Robert D. Willig. Contestable Markets and the Theory of Industry Structure, New York: Harcourt Brace Jovanovich, 1982.

Baumol, William J., John C. Panzar, and Robert D. Willig. "Contestable Markets: An Uprising in the Theory of Industry Structure: Reply", American Economic Review, 73, June 1983, p. 491-496.

Carlton, Dennis, W. and Jeffrey M. Perloff. Modern Industrial Organization, New York: Harper Collins Publishers, 1990.

Fernandez, Luis, and Eric Rasmusen. "Perfectly Contestable Monopoly and Adverse Selection”, Discussion Paper 93-016, Dept. of Economics, Indiana University, April 1993.

Fudenberg, Drew, and Eric Maskin. "The Folk Theorem in Repeated Games with Discounting or with Incomplete Information", Econometrica, 54, May 1986, p. 533-554.

Fudenberg, Drew, and Jean Tirole. Game Theory, Cambridge, MA: MIT Press, 1991.

Grossman, Sanford J. "Nash Equilibrium and the Industrial Organization of Markets with Large Fixed Costs”, Econometrica, 49, September 1981, p. 1149-1172.

Innes, Robert, and Richard J. Sexton. "Customer Coalitions, Monopoly Price Discrimination and Generic Entry Deterrence", European Economic Review, 37, December 1993, p. 15691597. 
Innes, Robert, and Richard J. Sexton. "Strategic Buyers and Exclusionary Contracts", American Economic Review, 84, June 1994, p. 566-584.

Katz, Michael L. "The Welfare Effects of Third-Degree Price Discrimination in Intermediate Good Markets", American Economic Review, 77, March 1987, p. 154-167.

Klein, Benjamin, Robert G. Crawford, and Armen A. Alchian. "Vertical Integration, Appropriable Rents, and the Competitive Contracting Process", Journal of Law and Economics, 21, October 1978, p. 297-326.

Machalaba, Daniel. "Tired of Costs, Delays of Railroads, Firms Lay Their Own Tracks", Wall Street Journal, February 6, 1998, p. A1.

Maskin, Eric, and Jean Tirole. “A Theory of Dynamic Oligopoly I: Overview and Quantity Competition with Large Fixed Costs”, Econometrica, 56, May 1988, p. 549-569.

Milgrom, Paul, and John Roberts. "Limit Pricing and Entry Under Incomplete Information: An Equilibrium Analysis", Econometrica, 50, March 1982, p. 443-459.

Rasmusen, Eric B. Games and Information, Cambridge, MA: Blackwell Publishers, Oxford 1994.

Rasmusen, Eric, Mark Ramseyer, and John Wiley Jr. "Naked Exclusion", The American Economic Review, 81, December 1991, p. 1137-1145.

Schmalensee, Richard L. Testimony of Richard L. Schmalensee, United States v. Microsoft, Civil Case 98-1232, January 11, 1999.

Schwartz, Marius, and Robert J. Reynolds. "Contestable Markets: An Uprising in the Theory of Industry Structure: Comment", American Economic Review, 73, June 1983, p. 488-490. 
Sennewald, Marc A. "The Nexus of Federal and State Law in Railroad Abandonments", Vanderbilt Law Review, 51, October 1998, p. 1399-1425.

Stefanadis, Chris. "Selective Contracts, Foreclosure and the Chicago School View", Journal of Law and Economics, October 1998, p. 429-450.

Tirole, Jean. The Theory of Industrial Organization, Cambridge, MA: MIT Press, 1988.

United Airlines. Comments and Proposed Rules on Computer Reservation Systems, EDR466, Docket no. 41686, before the Civil Aeronautics Board, November 17, 1983.

U.S. District Court. Final Judgement, United States v. Microsoft, Civil Action No. 941564, filed July 15, 1994.

Williamson, Oliver E. Markets and Hierarchies. New York: Free Press, 1975.

Williamson, Oliver E. "Transaction Cost Economics: The Governance of Contractual Relations", Journal of Law and Economics, 22, October 1979, p. 233-261.

Willig, Robert D. "Contestable Market Theory and Regulatory Reform", in John R. Allison and Dennis L. Thomas, eds, Telecommunications Deregulation: Market Power and Cost Allocation Issues, Connecticut and London: Greenwood, Quorum Books, 1990. 